\title{
TRANSFER IN RELATED SLAVIC LANGUAGES
}

(THIS ARTICLE WAS TRANSLATED FROM POLISH BY JAKUB WOSIK)

Keywords: transfer; intercomprehension; linguistic planes: phonetic, morphological, word-formation, lexical, stylistic; false friends

\begin{abstract}
In the field of teaching Polish as a foreign language, transfer plays a major role. Positive transfer helps the users of closely related Slavic languages learn more quickly, while negative transfer should be closely monitored. Intercomprehension is a phenomenon which consists of guessing the meanings of related words and linguistic forms, and the ability to quickly understand languages which are closely related to the mother tongue of learners; in other words, it is a case of positive transfer. Intercomprehension in teaching related languages is directly associated with the phenomenon of language transfer. In the practice of teaching Polish as a non-native language in Slovakia and Czechia, teaching methods related to intercomprehension, including a contrast-based approach, have been applied for a long time. However, more focus has always been placed on negative transfer. In this article we provide examples of the impact of transfer, usually negative, at several linguistic planes in learning Polish by Slovaks and Slovak by Poles. The first author indicates two planes, those of inflection and syntax, using examples from the works of Polish students; the second author discusses the problems associated with lexis and indicates three planes: those of word formation, lexis, and style. Their discussions indicate that similarities help master a language more quickly and how important highlighting the differences for learners is.
\end{abstract}

\section{INTERCOMPREHENSION AND LANGUAGE TRANSFER IN TEACHING RELATED LANGUAGES}

Intercomprehension can be defined as the ability to understand both the meanings of words, and morphological and syntactic structures, of the languages one acquires without ever having learnt them. The phenomenon of intercomprehension, i.e. rapid understanding, is particularly important in teaching related languages as their genetic proximity enables teachers to skip certain stages of the

"pancikova@chello.sk, University of Ostrava in Ostrava, Faculty of Philology, Chair of Slavic Studies, ul. Reální 5, 70103 Ostrava, (emeritná profesorka), ul. Jungmannova 6, 85101 Bratislava; Slovakia (home address).

** alexander.horak@gmail.com, ul. Medved’ovej 12, 85104 Bratislava, Slovakia. 
teaching process, otherwise necessary in teaching foreigners who speak languages which belong to other language families, and thus feature different structures. Intercomprehension in the teaching of related languages has a mainly linguistic dimension. It may also possess a cultural dimension which is reflected in similar linguistic politeness strategies, in lexis, and phraseology which reflects similar historical, cultural, ethnic, etc. experiences.

According to Gębal (2016), in teaching based on intercomprehension, focus is placed first of all on similarities, and only later on the differences in the systems of the languages being taught. An approach which emphasises differences is known in the teaching of non-native language as a contrastive approach.

When devising textbooks which apply this approach, one may refer to the similarities on all linguistic planes: in phonetics, to identical or similar pronunciations of phones; in morphology, to similar systems of inflective categories and their identifiers in the form of morphemes; in syntax, to similar rules of arranging words in collocations and sentences; and on the lexical plane in reference to the sets of lexical morphemes originating from the same source and having the same or similar meanings in both studied languages. For intercomprehension at the lexical level, what is also important are the processes of internationalisation, by virtue of which one finds in various languages many common lexemes which even if having slightly different spellings or morphological adaptations, still carry the same meanings. Miodunka was correct in arguing for the inclusion of graduates of other language studies in the groups of teachers of Polish as a foreign language. Based on our own experiences we also know that a teacher should have studied two languages, as then they are able to compare and select linguistic similarities and emphasise the differences.

When comparing the practices of teaching Polish and Slovak as non-native languages, one can conclude that the intercomprehensive approach is more commonly applied in Polish textbooks for teaching Polish as a foreign language than in Slovak textbooks for teaching Polish or Slovak/Czech as a foreign language. Most Slovak and Czech researchers of Polish favour the contrastive approach, cf. publications by Buffa (1997, 2001), Pančíková (1997, 2005, 2008), Damborski (1977), Lotko (1986a, 1986b), and the most recent textbook by Sokolová Slovenčina a pol’stina. Synchrónne porovnanie s cvičeniami (2012) for teaching Poles Slovak and Slovaks Polish. That also applies to teaching other Slavic languages, e.g. in the textbook by Baláž and Čabala Slovackij jazyk dl'a slavistov (1993) for learning Slovak by Russian-speaking learners. In the case of the most closely related Western Slavs, one can immediately start from a higher level, i.e. A2. For Czechs and Slovaks, Polish is related at many levels (pronunciation, text comprehension, and the ability to communicate one's thoughts). Even grammar is clearer when learners are shown what is common and when a teacher indicates differences between the languages. There are at least two books for learning Pol- 
ish for foreigners which intentionally utilise the mutual comprehensibility and the structural relatedness of languages (though it must be said that at the time when the books were released that was not yet defined as intercomprehension). Those are two textbooks by Pösingerová and Seretny Czy Czechów jest trzech? (1992) and Coraz bliżej Polski (1997), and a textbook by Pančíková and Stefańczyk Po tamtej stronie Tatr $(1998,2003)$.

In the beginner-level textbook Czy Czechów jest trzech? (1992) by Kateřina Pösingerová and Anna Seretny, when teaching communication in Polish at the A1 and $\mathrm{A} 2$ levels, the authors introduced more complex texts for reading comprehension, which basically correspond to the $\mathrm{B} 1$ and $\mathrm{B} 1+$ levels. They did so because they assumed that Czech students would be able to understand those texts, capitalising on the lexical similarities between the two West Slavic languages, i.e. Czech and Polish.

The same method was applied by the authors of the textbook for Slovaks entitled Po tamtej stronie Tatr. Their textbook (2003) has been classified for the A1 and A2 levels, i.e. for Slovaks only starting to learn Polish, yet who learn it more quickly as the source and target codes are closely related. In line with international standards, the textbook helps learners achieve the threshold level, i.e. B1. Its twelve lessons are preceded by an extensive commentary on phonetics, indicating the similarities and differences between the Polish and Slovak pronunciations. It also includes a set of exercises. Further lessons are devoted to inflection discussed "in an accelerated form". The textbook's texts were taken from various varieties of spoken and written language, and they are diverse in terms of their styles. Word lists for each lesson include Slovak equivalents of Polish lexical units: particular focus was placed on false friends and idioms. Thus, the textbook focussed on the contrastive approach between Polish and Slovak, i.e. on the similarities and differences which exist on all linguistic planes.

Intercomprehension in teaching related languages is directly related to the phenomenon of language transfer. In the broadest sense of the term, language transfer is understood as the impact of the mother tongue (or of any previously acquired language) on the acquisition of a foreign language (Odlin, 1989). One should stress at this point that the modern theory and practice of teaching non-native languages defines transfer as a process which has two outcomes: a positive one and a negative one. Negative transfer results in errors (mistakes) as former trained behaviour or habits do not overlap with the new ones. The other (i.e. positive) transfer consists of transposing correct habits and actions from an old (known) behaviour onto a new one (Lipińska, Seretny, Turek, 2016).

In the examples which we shall offer later in the article, we indicate how positive and negative transfers impact the acquisition of Polish by Slovaks and of Slovak by Poles. 


\section{THE LEVEL OF INFLECTION}

At the level of inflection, intercomprehension in teaching Polish and Slovak is facilitated by the extensive systems of grammatical, nominal and verbal categories, inherent in both languages, and inherited from the Proto-Slavic language. Both systems are largely similar, which is why it is not necessary to engage in special explanations of, e.g. the categories of the grammatical gender of nouns or of verb aspect, considered by some Slovak linguists (Baláž 1993; Dolník 2007) as the most difficult phenomena in teaching foreigners Slovak grammar, when teaching Poles Slovak and Slovaks Polish.

Concurrently, as some more recent Polish-Slovak studies have shown (Horák 2016), other identifiers of inflectional categories (e.g. different suffixes of specific cases) may also lead to negative transfers. In the case of Poles learning Slovak, that mainly applies to errors when inflecting nouns and adjectives throughout the cases in singular and plural, the lack of inflection of proper names and borrowings, the use of nominal forms of the genitive instead of possessive adjectives, errors in inflecting pronouns and numerals, and the creation of verb forms, including those created through an opposition of the masculine personal gender and non-personal gender in Polish and its absence in Slovak.

Examples:

a) gender

*Je to poriadna dávka adrenaliny.

Slovak: Je to poriadna dávka adrenalínu.

Polish: To porzadna porcja adrenaliny. [That's a decent dose of adrenaline]

b) Genitive singular

*Bolo tam vela mládežy z celého sveta.

Slovak: Bolo tam vel'a mládeže z celého sveta.

Polish: Było tam dużo mtodzieży z catego świata. [There were a lot of youths from around the world]

c) Accusative singular

*Preživajú osobnou tragédiu.

Slovak: Preživajú osobnú tragédiu.

Polish: Przeżywaja osobista tragedię. [They are experiencing a personal tragedy]

d) Locative singular

*Vo štvrtok po vyučovaniu hrám na harfe.

Slovak: Vo štvrtok po vyučovaní hrám na harfe.

Polish: $W$ czwartek po zajęciach gram na harfie. [On Thursdays after classes I play the harp] 
e) Instrumental singular

*Hlavným hrdinou filmu je Tóno.

Slovak: Hlavným hrdinom filmu je Tóno.

Polish: Glównym bohaterem filmu jest Tóno. [Tóno is the film's protagonist]

f) Past tense forms

*Videlam som tam dávneho kolegu.

Slovak: Videla som tam dávneho kamaráta.

Polish: Widzialam tam dawnego kolegę. [I saw there an old friend]

g) Future tense forms

*Cez prázdniny budeme ist' do Španielska.

Slovak: Cez prázdniny pôjdeme do Španielska.

Polish: $W$ wakacje będziemy jechać do Hiszpanii. [In the holidays we are going to Spain]

h) Conditional forms

*Velmi chcela bym som pracovat' ako učitel'ka.

Slovak: Velmi by som chcela pracovat' ako učitel'ka.

Polish: Bardzo chciałabym pracować jako nauczycielka. [I would very much

like to work as a teacher]

\section{THE LEVEL OF SYNTAX}

Intercomprehension at the level of syntax between Polish and Slovak is possible by dint of numerous similarities between the two linguistic systems. Nonetheless, Polish, and Slovak feature many differences at this linguistic level (cf. Sokolová et al. 2012), which usually result in negative transfer.

Horák's analysis (2016) of how Poles acquire Slovak has indicated that Poles who learn Slovak use structures with impersonal verb forms and with gerund forms which in Slovak do not exist. They also use a different verbal case government within syntactic accommodation, they formulate sentences with elliptical auxiliary verb to be in complex predicates, and they have a clear tendency to use the Polish word order in sentences, which is visible particularly in the post-position of the adjunct, as well as in the order of enclitics. An analysis at the syntactic level has proven that negative transfer is evident in linguistic structures in terms of which Polish and Slovak differ considerably.

Examples:

a) aby/żeby [to/ in order to] + infinitive

*Momentálne nemám čas, aby sa stretávat's priatelmi.

Slovak: Momentálne nemám čas, aby som sa stretávala s priatel’mi.

Polish: Teraz nie mam czasu, aby się spotykać z kolegami. [Now I don't have time to meet my friends] 
b) lubię [I like] + infinitive

*Cesta je vel'mi úzka, nemám rada tam chodit' bicyklom.

Slovak: Cesta je vel'mi úzka, nerada tam chodím bicyklom.

Polish: Droga jest bardzo waska, nie lubię tędy jeździć rowerem. [The road is very narrow, I don't like riding my bike here]

c) structures with gerund forms

*V tamtych časach bola pre nás cesta do Nemecka ňe do pomyslenia.

Slovak: $V$ tých časoch bola pre nás vtedy cesta do Nemecka nemyslitel'ná.

Polish: $V$ tamtych czasach podróż do Niemiec byta dla nas nie do pomyślenia.

[In those times, a journey to Germany was for us something not to be imagined]

d) structures with impersonal verb forms

*Výpredano 20500 kínových vstupenok.

Slovak: Predali 20500 listkov do kina.

Polish: Sprzedano 20500 biletów do kina. [20,500 cinema tickets were sold]

e) verb case government - genitive

*V júni sa musím pripravovat’ do skúšky.

Slovak: V júni sa musím pripravovat' na skúšku.

Polish: $W$ czerwcu muszę się przygotowywać do egzaminu. [In June, I must prepare for the exam]

f) verb case government - locative

*Strávili sme tri dni na prehliadke mesta.

Slovak: Strávili sme tri dni prehliadkou mesta.

Polish: Spędziliśmy trzy dni na zwiedzaniu miasta. [We spent three days sightseeing]

g) ellipsis of the byt' verb

*Postmoderna to [] všetko, čo nás obklopuje.

Slovak: Postmoderna je všetko, čo nás obklopuje.

Polish: Postmodernizm to wszystko, co nas otacza. [Postmodernism [ ] everything that surrounds us]

h) erroneous word order - adjunct

*Študoval filológiu anglickú na Jagelovskej univerzite.

Slovak: Študoval anglickú filológiu na Jagelovskej univerzite.

Polish: Studiowat filologię angielska na Uniwersytecie Jagiellońskim. [He studied Polish philology at the Jagiellonian University]

i) erroneous word order - personal pronouns

*Velmi mi sa páči hudba z filmu Titanic.

Slovak: Vel’mi sa mi páči hudba z filmu Titanic.

Polish: Bardzo mi się podoba muzyka z filmu Titanic. [I very much enjoy the Titanic soundtrack] 
j) erroneous word order - reflexive verbs

*Staré Mesto velmi sa mi páčilo.

Slovak: Staré Mesto sa mi velmi páćilo.

Polish: Starówka bardzo mi się podobała. [I very much like the old town]

k) erroneous word order - the past tense

*V Bratislave naučila som sa, že všetko, čo je rakúske, je dobré.

Slovak: V Bratislave som sa naučila, že všetko, čo je rakúske, je dobré.

Polish: W Bratystawie nauczytam się, że wszystko, co austriackie, jest dobre. [In

Bratislava, I learnt that everything Austrian is good]

1) erroneous word order - the conditional mood

*Sused hovorí, že mala by som sa viac pohybovat.

Slovak: Sused hovorí, že by som sa mala viac pohybovat'.

Polish: Sąsiad mówi, że powinnam się więcej ruszać. [My neighbour says

I should move more]

\section{THE LEVEL OF WORD FORMATION}

At the level of word formation, there also exist similarities and differences in both analysed language systems. That has been confirmed in comparative studies of Polish and Slovak by specialists in the area (e.g. Mieczkowska 2015; Pančíková 2008; Sokolová et al. 2012; Vojteková 2016). The means of creating new lexis are similar, yet both languages use specific affixes with different frequency and in somewhat different ways. Those differences usually result in instances of negative transfer.

The quoted examples came from dictionary resources and the publications by the co-author of this article (more extensive analyses can also be found therein):

a) application of different affixes for creating new words - using the Polish -owy suffix instead of the Slovak -ny:

Polish

dodatkowy

międzynarodowy

posezonowy

b) different affixes in borrowings

Polish

agencja

humanizm

moralność

recykling

republikanin

solidarność

suwerenność

totalizm/totalitaryzm
Slovak

dodatočný [additional]

medzinárodný [international]

posezónny [post-seasonal]

Slovak

agentúra [agency]

humánnost' [humanism]

morálka [morality]

recyklácia [recycling]

republikán [a republican]

solidarita [solidarity]

suverenita [sovereignty]

totalita [totalism/ totalitarianism] 
c) application of the same suffix for creating names which have different meanings; the examples we quoted indicate that it is not always the case that one affix can apply to an identical word-formation and semantic category in the other language. In Polish and Slovak, forms are created in an identical manner, yet their meanings are different.

$\begin{array}{ll}\text { Polish } & \text { Slovak } \\ \text { kosmetyk, kosmetyczka } & \text { kozmetik, kozmetička } \\ \text { (NR, object: 'a substance' and 'a bag') } & \text { (NAg - 'a person') } \\ \text { wojaczka } & \text { vojačka } \\ \text { (NAc - 'military service', 'warring') } & \text { (NAg - 'a person', 'a woman') } \\ \text { kopaczka } & \text { kopačka } \\ \text { (NI - 'a farming machine') } & \text { (NR - 'one of cleats') } \\ \text { letniczka } & \text { letnička } \\ \text { (NAtr. 'a woman', 'a summer vacationer') } & \text { (NR - 'an annual plant')1 }\end{array}$

\section{THE LEVEL OF LEXIS}

In Slavic languages, there are many words which have common roots, identical origins, and once had common meanings. The most closely related languages which belong to the Western branch, i.e. Polish, Czech, and Slovak, developed from a common linguistic basis, which is why many words sound similar and their original meanings were similar. Later development, separately, resulted in changes to the meanings of individual lexemes, which resulted in the emergence of inter-language homonyms commonly referred to as false friends, traps, or treacherous words. In genetically closely related languages, they are a source of constant misunderstandings.

Inter-language homonymy is an outcome of the semantic differentiation of a common native and borrowed lexical stock, or accidental compliance of word forms or word-formative affixes. Finally, within the process of creating new words, means of word formation which are common for both languages are sometimes used differently by them, a fact which results in misunderstandings. False friends in closely related languages cause many misunderstandings in communication and in translations, which is why teachers must warn learners about such lexical pitfalls.

${ }^{1}$ The abbreviations used in the examples came from the Latin names of word formation categories (known in Czech, Polish and Slovak studies on word formation: Dokulil 1962; Daneš et al. 1967; Grzegorczykowa 1972; Pančíková 2008): NAc - names of activities, NAg - names of actors, NAtr. - names of possessors of features, NR and NP - names of objects, items and products of activities, NI - names of tools. 
We selected a few examples from a bilingual Slovak-Polish dictionary and publications on false friends (Pančíková 2005).

In Slovak, the stan lexeme denotes 'a tent', while in Polish it is an abstract noun denoting 'a situation', 'a plight', or 'conditions'. The Slovak equivalent of the Polish stan lexeme is stav, while staw in Polish denotes 'a reservoir' or 'a part of the human body' - in Slovak those are two completely different words: the former meaning is denoted by the phrase 'vodná nádrž' while the latter is denoted by the word 'kĺb'.

The Polish verb kurzyć [to dust] has the Slovak equivalent of 'prášit', sypat' sa' while the Slovak kúrit' has the Polish equivalent of 'to burn in a furnace, to warm up'.

The Polish word modraki has the Slovak equivalent of 'nevädza - a cornflower', while the Slovak word modráky is 'a common name of a wild mushroom - a bluing bolete' and has another meaning of 'blue work overalls'.

There are numerous similar examples; in the following table we include a few selected examples of Polish-Slovak false friends:

\begin{tabular}{|c|c|c|c|}
\hline $\begin{array}{l}\text { Polish word } \\
\text { mizeria (cucumber and cream salad) }\end{array}$ & $\neq$ & $\begin{array}{l}\text { Slovak word } \\
\text { mizéria (poverty) }\end{array}$ & $\begin{array}{l}\text { Correct Slovak equivalent } \\
\text { uhorkový šalát }\end{array}$ \\
\hline palec (a finger) & $\neq$ & palec (a thumb) & prst \\
\hline pański (yours (plural)) & $\neq$ & panský (Lord's) & váš \\
\hline pogoda (the weather) & $\neq$ & pohoda (an idyll) & počasie \\
\hline pokład (a deck) & $\neq$ & poklad (a treasure) & paluba \\
\hline rozktad (a plan) & $\neq$ & rozklad (decay) & rozvrh \\
\hline siostrzenica (a niece) & $\neq$ & sesternica (a cousin) & neter \\
\hline stawiać (to buy) & $\neq$ & stavat' (to build) & platit' \\
\hline stopa (a foot) & $\neq$ & stopa (a trace) & chodidlo \\
\hline szykować (to prepare) & $\neq$ & šikovat' (to lead) & pripravovat' \\
\hline
\end{tabular}

\section{THE LEVEL OF STYLE}

Misunderstandings in related languages may be also caused by differences in stylistic undertone as there are various words which differ from one another only in terms of their stylistic qualifiers. Knowing all the undertone variants of a word is particularly important for translators, lexicographers, and teachers. In the definition of false friends, that was first mentioned by Lotko (1992), a Czech researcher of Polish, and later also the author of this article in her publications (Pančíková 2005). 
The examples of an incorrect selection of linguistic means in specific utterances (official vs. colloquial), i.e. stylistic treachery also came from her publication:

Polish

bagaż [baggage] ('batožina') neutral

egzamin [an exam] neutral

grunt [ground] neutral

hamować [to brake] neutral

list ('rastliny') old-fashioned

muzyka [music] neutral

plac [a square] neutral

powinność [obligation] literary
Slovak

bagáž old-fashioned

egzámen old-fashioned, literary

grunt old-fashioned

hamovat' colloq.

list [a letter] neutral

muzika colloq.

plac colloq.

povinnost' neutral

All of the provided words have the same meaning, but different stylistic qualifiers, which may cause translation problems. By the same virtue, the use of a word with any qualifier may be unacceptable in academic or professional texts. That is why students of translation studies must be aware of the importance of choosing the right words.

\section{CONCLUSION}

Intercomprehension, a phenomenon which consists of deducing the meanings of words and the structures of related languages, enables one to quickly master closely related languages. In the practice of teaching Polish in Slovakia and Czechia, intercomprehension had long been used before the term was used in the study of teaching foreign languages. The many years of our professional practice have proven that similarities, by dint of the mechanism of positive transfer, help in learning a language more quickly. Yet it is important to make learners aware of the differences which might lead to negative language transfer, i.e. instances of interference at various levels of language: inflection, syntax, word formation, lexis, and style.

\section{BIBLIOGRAPHY}

Baláž P., Čabala M., Darovec M., 1993, Slovackij jazyk dla slavistov, Bratislava.

Buffa F., 1998, Z pol'sko-slovenských jazykových vztahov. Konfrontačný náčrt, Prešov.

Buffa F., 2001, Z pol'sko-slovenských lexikálnych vzt'ahov. Konfrontačný náčrt, Prešov.

Damborský J., 1977, Studia porównawcze nad stownictwem i frazeologia polska i czeska, Warszawa.

Daneš F., Dokulil M., Kuchař J., 1967, Tvoření slov v češtině 2. Odvozování podstatných jmen, Praha. 
Dokulil M., 1962, Tvoření slov v češtině 1. Teorie odvozování slov, Praha.

Dolník J., 2007, Súčasná spisovná slovenčina a jej problémy, Bratislava.

Gębal P.E., 2016, Interkomprehensja, strategie mediacyjne i nauczanie języków obcych, in: E. Lipińska, A. Seretny (eds.), Ttumaczenie dydaktyczne w nowoczesnym kształceniu językowym, Kraków, pp. 77-93.

Grzegorczykowa R., 1972, Zarys stowotwórstwa polskiego. Czesść 1. Stowotwórstwo opisowe, Warszawa.

Horák, A., 2016, Pol’sko-slovenská medzijazyková interferencia vo výučbe slovenčiny ako cudzieho jazyka (unpublished doctoral dissertation), Jagiellonian University, Kraków.

Lipińska E., Seretny A., Turek P., 2016, Btędy pragmatyczne w nauczaniu języka polskiego jako obcego, in: E. Lipińska, A. Seretny (eds.), Ttumaczenie dydaktyczne w nowoczesnym ksztatceniu językowym, Kraków, pp. 183-200.

Lotko E., 1986a, Polština a čeština z hlediska typologického, Olomouc.

Lotko E., 1986b, Čeština a polština v prekladatelské a tlumočnické praxi, Ostrava.

Lotko E., 1992, Zrádná slova v polštině i češtině, Olomouc.

Mieczkowska H., 2015, Zapożyczenia a paralele słowotwórczo-leksykalne w rozwoju leksyki przetomu wieków (w ujęciu stowacko-polskim), Kraków.

Miodunka W.T., 2010, Glottodydaktyka polonistyczna $w$ dobie globalizacji i informatyzacji, Kraków.

Odlin T., 1989, Language transfer: cross-linguistic influence in language learning, Cambridge.

Pančíková M., 1997, Polsko-stowacka interferencja (swoistość nauczania języka polskiego Stowaków), in: W.T. Miodunka (ed.), Nauczanie języka polskiego jako obcego, Kraków, pp. 215-219.

Pančíková M., 2005, Zradnosti pol’skej a slovenskej lexiky, Opole.

Pančíková M., 2008, Rozvojové tendencie pol'skej a slovenskej lexiky na prelome tisicročia. Vybraná problematika. Substantiva, Bratislava.

Pančíková M., Horák A., 2018, Polonistyka na poczatku XXI wieku. Diagnozy - koncepcje - perspektywy, in: J. Tambor, A. Achtelik, K. Graboń (eds.), W kręgu glottodydaktyki. vol. 5., Katowice, pp. 519-533.

Pančíková M., Stefańczyk W., 1998, Po tamtej stronie Tatr, Kraków.

Pančíková M., Stefańczyk W., 2003, Po tamtej stronie Tatr. Supplemented and amended, Kraków.

Pösingerová K., 2001, Interferencja i nauczanie języka polskiego, Katowice.

Pösingerová K., Seretny A., 1992, Czy Czechów jest trzech? Učebnice polského jazyka pro Čechy - díl I, Kraków.

Pösingerová K., Seretny A., 1997, Coraz bliżej Polski. Učebnice polského jazyka pro Čechy-díl II, Praha - Kraków.

Sokolová M., Vojteková M., Mirosławska W., Kysel’ová M., 2012, Slovenčina a pol’ština: synchrónne porovnanie s cvičeniami, Prešov.

Vojteková M., 2016, Slovenské a pol’ské adjektívum z aspektu slovotvornej motivovanosti, Prešov. 
Marta Pančiková, Alexander Horák

\section{INTERKOMPREHENSJA W BLISKICH JĘZYKACH SŁOWIAŃSKICH}

Słowa kluczowe: interkomprehensja, płaszczyzna językowa - fonetyczna, morfologiczna, słowotwórcza, leksykalna, stylistyczna, wyrazy zdradliwe

Streszczenie. Interkomprehensja to zjawisko odgadywania znaczeń wyrazów i struktury języków pokrewnych, zdolność szybkiego rozumienia języków blisko spokrewnionych z językiem ojczystym uczących się. W glottodydaktyce nauczania języka polskiego w Słowacji i w Czechach interkomprehensję stosowano już dawno. Interkomprehensja w nauczaniu języków pokrewnych bezpośrednio jest związana ze zjawiskiem transferu językowego. W tym artykule podajemy przykłady na oddziaływanie transferu pozytywnego i negatywnego na różnych płaszczyznach językowych w przyswajaniu języka polskiego przez Słowaków i języka słowackiego przez Polaków. Potwierdza się, że podobieństwa pomagają szybciej opanować język i ważne jest uczulanie uczących się na różnice. Interkomprehensja w nauczaniu języków pokrewnych ma przede wszystkim wymiar językowy, ale może mieć również wymiar kulturowy. 